\title{
Study of University Students' Social Competence Development
}

\author{
Gulfiya G. Parfilova ${ }^{1} \&$ Lilia Sh. Karimova ${ }^{1}$ \\ ${ }^{1}$ Kazan (Volga region) Federal University, Kazan, Russia \\ Correspondence: Gulfiya G. Parfilova, Kazan (Volga region) Federal University, Kremlyovskaya Street 18, \\ Kazan, 420008, Russia.
}

Received: January 19, 2014

doi:10.5539/res.v7n5p10
Accepted: February 22, 2015 Online Published: March 25, 2015

URL: http://dx.doi.org/10.5539/res.v7n5p10

\begin{abstract}
The aim of the study was to investigate and diagnose university students' social competence, as well as to develop and implement the program, containing a variety of forms and methods of formation of university students' social competence. For this purpose, there was carried out the experiment, which involved 150 students of Kazan Federal University. The experiment applied complex diagnostic techniques to identify the level of social intelligence, empathic abilities, conflict-resolution strategies. On the basis of the results of stating experiment there was developed a program containing forms and methods of university students' social competence formation. Statistical analysis of empirical research was done by means of standardized testing assessment in mathematical statistics (Student's t-test).
\end{abstract}

Keywords: competence, social competence, social intelligence, university students

\section{Introduction}

\subsection{Actualizing the Problem}

Current social challenges in Russia put forward new and higher requirements for professional training and formation of the personality of future specialists. There is an urgent need for continuous improvement of highly-professional staff training system, the creation of a holistic concept of professionalization and identification of forms in which it occurs. The main focus should be on the personality of a specialist, his attitude to the profession and to other people, because it affects the future success of professionalization. Today a specialist is required to confront professional challenges, manifest perceptual abilities, understand the individual and unique character of other people, manage his emotional state and determine the power of his impact. A competent person must be able to quickly and adequately understand the statements of other people, to possess communication skills and have peculiar knowledge about the variety of social roles and ways of interacting. (Zakirova \& Koletvinova, 2014; Ivanenkoet al., 2015; Merzon et al., 2015; Sakhievaet al., 2015; Kalimullin, 2014, 2015; Ganieva et al., 2014, 2015; Biktagirova \& Valeeva, 2013, 2014). The effectiveness of university graduate depends primarily on his ability to work with people, to listen and understand, empathize with others, by means of productive behavior in challenging situations, which is hard to do, if his social competence is not developed. Thus, social competence of a specialist is considered integral to his professional competence (Mokeyeva et al., 2015; Gabdulchakov \& Yashina, 2014).

\subsection{Explore Importance of the Problem}

Changing socioeconomic status of modern society and renovating of the educational system require a new level of specialists' professionalism. In this regard, of particular importance is the problem of training qualified personnel, ready to solve professional problems theoretically and practically, able to create, apply and adjust the system of professional activity. The main result of educational institutions' fuctioning should be an acquired set of core competencies in various fields rather than a system of knowledge and skills (Lisitzina et al., 2014; Sibgatova et al., 2015; Vlasova et al., 2015).

Traditionally, the goal of higher education was to give knowledge and develop skills of a graduate. To date, this approach has proved insufficient. Modern society needs graduates who are ready for further life activity and able to practically solve daily and professional challenges facing them. It depends not on the acquired knowledge and skills, but on some additional qualities that are identified under the term "competence" which is more appropriate for understanding modern educational purposes. Among the key competences of a university graduate of special importance is social competence. 


\subsection{Status of the Problem}

The issue of competence formation of specialists of different fields is the subject of study of many modern Russian researchers: Vardanyan (1999), Zimnyaya (2006), Verbitski (2004), Zeer (2003), Khutorskoy (2003), Shaidullina et al. (2015), Lopatina et al. (2015), Zaripova et al. (2014), Gutman et al. (2014), Valeeva, Koroleva and Sakhapova (2014), Masalimova et al. (2014), Gatiyatullin and Nigmatov (2014), Ivanov, Shaidullina, Drovnikov, Yakovlev and Masalimova (2015). The term "competence" (Latin "competentia") means a set of issues that an individual is well aware of and has acquired experience in. Zimnyaya (2006) understands "competence" as an actual, subject to forming personal quality based on knowledge, intellectually and personally stipulated socio-professional characteristic of a person, his personality quality. The analysis of presented definitions of competence concept allows to conclude that competence is connected with a certain set of knowledge and skills, abilities and personality qualities that are successfully applied in professional activity and developed in the process of study and upbringing.

Social competence takes the leading position in the hierarchy of values and is defined as a person's ability and readiness to manage his relations with the social realm and other people efficiently. In the 1980-s and 1990-s many scientists handled the issue of social competence and created complimentary models (Hinsch \& Vitman, 2005; Selman, 1997). They define social competence as the possession of cognitive, emotive and motor ways of behaviour which in certain social situations promote long-term favourable balance of positive and negative consequences. Within the frames of English-American research position, Rubin (2001) and other scientists understand social competence as effectiveness and adequateness of an individual's reflection of various problem situations in life, and the ability to overcome them. Argile (1962) combining professional and communicative competencies determines a social competence as obtained skills and ways of behavior that allow an individual to display desirable impact on other people and ascribes such signs as social sensitivity, general skills of social interaction and skills of encouraging and reward, balance and quietness.

In some researches "social intelligence" is often considered as the counterpart of a social competence. The concept social intelligence was firstly used by Thorndike (1920) in 1920 to specify "foresight in interpersonal relations". Many famous psychologists contributed to the interpretation of this notion. In 1937, Allport (1973) described social intelligence as a specific ability to judge people in the right way, to predict their behavior, and to provide adequate interpersonal interaction. According to G. Allport, social intelligence is a special "social gift" that makes people's relationships smooth and is characterized by social adaptability instead of the depth of understanding (Allport, 1973).

Thus, the main characteristics of social competence are developed social intelligence, empathy, ability to handle conflict situations efficiently.

The problems of social competence have only recently become a subject of special consideration in the Russian psycho-pedagogical works. There is an increasing interest in modern psychological and pedagogical science in various aspects of social competence (Basova, 2004; Bakhteeva, 2001; Vorontsov, 2006; Kalinin \& Lukjanova, 2003; Koblyanskaya, 1995; Kunitsyna, 1995). Markova (1990) identifies the content of social competence as the mastering of mutual (group, co-operative) professional activity, collaboration, and methods of professional training adopted for this profession, responsibility for the results of work. According to Kunitsyna (1995), the ability of a person to show his empathy towards another person and to solve conflict situations adequately make the essence of social competence. She defines social competence as the system of knowledge about social reality and oneself, the system of complex social skills of interaction, scenarios of behavior in typical social situations to get adapted quickly and adequately, to take reasonable decisions.

Considering this variety of competence as one of the basic characteristics of a personality Romulus (2003) singles out its basic structures: knowledge (possession of some information), attitude to this knowledge (accepting or rejecting, ignoring, transforming), implementation (practical application of knowledge); secondly, taking into consideration such aspects of social competence as ability to take in the social structure of the society, announcing positive social initiatives, taking responsibility for their realization, participating in the activity of public organizations and associations.

Thus, social competence is attributed as the ability to communicate, cooperate, to handle conflicts, to achieve goals, to adapt easily, to display the initiative, to take responsibility etc. (Valeeva \& Karimova, 2014).

However, paying tribute to scientists' researches that reveal the essence of competence, its various types, ways and conditions of their development, it should be noted that the issues of formation of social competence of future professionals have not been sufficiently studied yet. 


\subsection{The Trial Infrastructure and Stages of the Research}

An empirical study was conducted on the basis of Kazan (Volga Region) Federal University. It involved 150 full-time students of the first, second and third courses. The study was done in three stages: stating, forming and controlling.

Stating experiment covered evaluation of the gnostic, intellectual, emotional and behavioral indicators of reflective social competence of university students. On the basis of the results there was developed a program containing a variety of forms and methods for the formation of social competence of students.

The aim of the forming experiment was to implement the experimental work aimed at the use of the developed forms and methods for the formation of social competence of students.

At the controlling stage of the experiment there was evaluated the effectiveness of the forms and methods of formation of social competence of students. At this stage there was identified the level of all indicators of formation of social competence of students and studied their dynamics.

\subsection{Evaluation Criteria}

In the structure of social competence there were identified the following indicators: intellectual and gnostic, emotional and reflective, behavioral, which were investigated in the course of experimental work.

Intellectual and gnostic indicator of social competence implies possession of certain knowledge in the field of social interaction, which includes not only the knowledge of oneself, but also the ability to know the other person, to understand his intentions, feelings and state by verbal and non-verbal manifestations; awareness of the importance of knowing diverse methods of communication needed for the enrichment of social and subjective experience in the life and professional self-determination.

Emotional and reflective indicator is the ability to monitor and analyze one's emotional state; possession of skills of self-analysis, self-organization and self-motivation; the ability not only to listen but also to understand and empathize with the other person (empathy).

Behavioral indicator implies having individual activities focused on creative self-development; the ability to adapt to new situations of social and pedagogical interaction; the ability to control one's behavior in a conflict situation and choose the right strategy for one's behavior.

\subsection{Experimental Procedure and Its Description}

For each of the indicators (intellectual and gnostic, emotional and reflective, behavioral) there were determined three-level criteria measuring manifestation of students' social competence.

The high level of students' social competence development. Students are active and creative; they are able to extract maximum information about the behavior of people by communication, to understand the language of non-verbal communication, to show foresight in dealing with other people, which contributes to their successful social adaptation, to find a compromise solution and the best way to handle conflicts, to listen and hear the other party, to make responsible decisions, to demonstrate confident behavior in situations of social interaction, to display self-restraint and self-control.

The average level of students' social competence development. Students possess advanced skills in independent learning, have limited ability to understand the other party and difficulty in dealing with conflict situations, are balanced, though in difficult communication situations are often irritated and may lose control of their emotions, in situations of social interaction might be highly insecure.

The low level of students' social competence development. Students cannot analyze their and other people's behavior, have poor knowledge of body language, are increasingly focused on the verbal content in communication, have difficulty in analyzing situations of social interaction and, as a result, aren't able to adapt to various types of relationships between people in conflict situations, do not consider their own as well as their partners' abilities, are highly passive in social activities.

\section{Results}

At the stating stage of the experiment, due to the results of the intellectual and gnostic characteristic research according to G. Guilford's procedure, we found out that students can deal with non-verbal reactions rather well, they are able to communicate successfully with different people in different situations, but a low level of "Story Additions" test ( 8 points) testifies to the fact that students have some difficulties when analysing situations of interpersonal interaction and, as a result, have poor adaptation abilities to establish relationships with different people. The general level of social intelligence development was determined on the basis of the total sum of each 
test and the indicator of a social intelligence complex assessment in the group made 31 points at that stage, it corresponds to the third (average-developed) level of social intelligence.

The integral indicator of empathic abilities in the group at this stage made 18, 26 points, it corresponds to the understated level of students' abilities.

The results of Thomas test demonstrated that the majority of the group participants choose such behavior strategies in conflict situations as adjustment ( 7,04 points), avoidance $(6,67$ points), rivalry ( 9,07 points). The results of all three indicators of the stating experiment showed that the level of students' social competence is rather low. The goal of the forming experiment was to conduct some experimental work aimed at the realization of the developed pedagogical conditions that impact social competence formation.

At the stage of forming experiment, there were tested different versions of the experimental material: questionnaires, interviews, observation, there were developed exercises to promote the development of social competence and various exercises for theoretical courses, trainings, there was implemented a program containing a variety of forms and methods for the formation of social competence (Vachkov, 2005). All methods met the goals and specific tasks of the research, provided the ways for quantitative and qualitative analysis of indicators that suggest the objective consideration of the results of the research. During the experiment, there was observed an increasing activity of students, improved cognitive activity, desire for self-development, which suggests the effectiveness of the forms and methods used.

At the controlling stage of the experiment there was evaluated the effectiveness of the forms and methods of students' social competence formation.

Having analyzed the results of average values in the group before and after the experiment, we noticed that the results of the subtest "A story Ending Test" increased from 8 to 11 points. It can testify that students have well-formed skills to anticipate people's further actions, and arrange guidelines of their behavior to achieve the desired goals. The increased indicator of "Expression Testing" (from 9 to 12 points) gives reason to say that a student can properly estimate states, feelings, intentions of other people according to their non-verbal manifestations, mime, postures, gestures. According to the results of four subtests, the average level of social intelligence has increased (the 5th level). Individuals with high social intelligence level are able to get the utmost information about people's behavior, to understand the language of non-verbal communication, to display foresight dealing with other people to promote successful social adaptation.

The value of the empathic abilities integral indicator has increased significantly from 18,26 to 22,16 points.

The retest was carried out with the application of Thomas test-questionnaire as well. Thus, if at the controlling stage students possessed such strategies as adjustment and avoidance, which according to G. Thomas are not considered as successful strategies to manage conflicts, then at the stating stage, cooperation $(9,65)$ and compromise $(8,26)$ had the highest score. These strategies of behavior are effective for conflict management, in case of cooperation strategy application both sides gain the advantage. It is also important to state that scores of rivalry and avoidance strategies decreased though at the stating stage they had a high rate.

The changes of average values in the students' group before and after the experiment were tested for their reliability with Student's T-criterion. The following data were obtained after calculations: $\mathrm{t}_{\mathrm{cr}}=1,98($ at $\mathrm{p}<0,05)$, $t_{c r}=2,62($ at $p<0,01)$. As temp $>t_{c r}$, the differences between behavior strategies in conflict situations gained at the pre-test and post-test stages of the experiment do exist and they are significant.

Comparative analysis of the results obtained in four techniques conducted at the beginning of the experimental work showed that among the surveyed students $33.7 \%$ of them had a low level of social competence development, $43.5 \%$ of students had an average level of social competence development, $22.8 \%$ of students had a high level of social competence development. During the re-diagnosis, it was revealed that the number of members in leveled groups has changed. The number of students with a low level of development of social competence (from 33.7\% to 15\%) has decreased and the number of students with average and high levels (from $43.5 \%$ to 47.7 and from 22.8 to $37.3 \%$, respectively) has increased. 
Table 1. Levels of social competence development in the experimental group before and after the experiment (in\%)

\begin{tabular}{llllclcc}
\hline Group & \multicolumn{4}{c}{ Levels of social competence development } \\
\cline { 2 - 7 } & \multicolumn{3}{c}{ Low } & \multicolumn{3}{c}{ Average } & \multicolumn{2}{c}{ High } \\
& before & after & before & after & before & after \\
\hline The experimental group & 33.7 & 15 & 43.5 & 47.7 & 24.8 & 37.3 \\
\hline
\end{tabular}

\section{Discussions}

The most important conditions that contribute to students' social competence formation within the framework of educational institutions are turning educational institutions into an open social and pedagogical system, employing highly professional teaching staff, as well as creating a favorable psychological climate. In an educational institution there should be created such a social environment that will help the development of tolerant forms of interaction among students and their willingness to understand the other people.

\section{Conclusion}

Thus, the results of the experimental work show the dynamics before and after the experiment. After the experiment students have a high level of social intelligence, the level of their empathic and reflective abilities has increased, in conflict situations they prefer such behavioral strategies as cooperation and compromise. The observation has also revealed that students started behaving confidently in situations of social interaction and became creative and active.

Growth dynamics of social competence apart from developed complex forms and methods of teaching is proved by the following factors: collaboration between teachers, constant keeping a high level of students' motivation, the use of active teaching methods, organization of independent work of students.

\section{Acknowledgments}

The work is performed according to the Russian Government Program of Competitive Growth of Kazan Federal University

\section{References}

Allport, G. W. (1947). Personality: A psychological interpretation. New York: Holt, Rinehart, \& Winston.

Argyle, M., \& Robinson, P. (1962). Two origins of achievement motivations. British journal of social and clinical psychology, 1. http://dx.doi.org/10.1111/j.2044-8260.1962.tb00690.x

Bakhteeva, S. S. (2001). Formation of a professional's social competence in the process of teaching a foreign language in the institute of economics (Doctoral dissertation). Kazan.

Basova, V. M. (2004). Theory and practice of personality social competency formation. Kostroma: KSU named after N.A. Nekrasov.

Biktagirova, G. F., \& Valeeva, R. A. (2013). Technological approach to the reflection development of future engineers. In 2013 International Conference on Interactive Collaborative Learning (p. 427). http://dx.doi.org/10.1109/ICL.2013.6644615

Biktagirova, G. F., \& Valeeva, R. A. (2014). Development of the teachers' pedagogical reflection. Life Science Journal, $11(9), 60-63$.

Boyko, V. V. (2004). The energy of emotions in communication. St. Petersburg: "Piter".

Gabdulchakov, V. F., \& Yashina, O. V. (2014). Prevention of latent national aggression in the course of future teacher education. Asian Social Science, 11(2), 270-276.

Ganieva, Y. N., Azitova,G. S., Chernova, Y. A., Yakovleva, I. G., Shaidullina, A. R., \& Sadovaya,V. V. (2014). Model of high school students' professional education. Life Science Journal, 11(8), 504-509.

Ganieva, Y. N., Sayfutdinova, G. B., Yunusova, A. B., Sadovaya, V. V., Schepkina, N. K., Scheka, N. Y., Gutman, E. V., \& Salakhova, V. B. (2015). Structure and content of higher professional school lecturer education competence. Review of European Studies, 7(4), 32-37. http://dx.doi.org/10.5539/res.v7n4p32

Gatiyatullin, M. K., \& Nigmatov, Z. G. (2014). Formation of entrepreneurship culture with technical university students. Middle-East Journal of Scientific Research, 19(4), 544-560.

Gutman, Y. Y., Masalimova, A. R., Shaidullina, A. R., Nizamieva, A. M., \& Myhamadieva, A. H. (2014). Foreign 
Language discipline integrative potential in the students' research competence forming. American Journal of Applied Sciences, 11(7), 1099-1103. http://dx.doi.org/10.3844/ajassp.2014.1099.1103

Hinsh, R., \& Vittman, S. (2005). Social competency. Kharkov: Gumanitarny Tzentr Publishers.

Ivanenko, N. A., Akhmetov, L. G., Lavrentiev, S. Y., Kartashova, E. P., Lezhnina, L. V., Tzaregorodtzeva, K .A., \& Khairullina, E. R. (2015). Features of Modeling the Formation of Teaching Staff Competitiveness. Review of European Studies, 7(3), 37-42. http://dx.doi.org/10.5539/res.v7n3p37

Ivanov, V. G., Shaidullina A. R., Drovnikov A. S., Yakovlev S. A., \& Masalimova, A. R. (2015). Regional Experience of Students' Innovative and Entrepreneurial Competence Forming.Asian Social Science, 11(1), $35-40$.

Kalimullin, A. M. (2014). Improvement of teachers' qualification at Kazan federal university. World Applied Sciences Journal, 30(4), 447.

Kalimullin, A. M. (2015). Ecological problems of middle Volga in the second half of the XXth century: Historical and ecological analysis of leading industrial regions development. Review of European Studies, $7(1), 86$.

Kalinina, N. V., \& Lukyanova, M. I. (2003). Psychological aspects of students' social competence development. Ulyanovsk: UIPKRO.

Khutorskoy, A. V. (2003). Key competences. Technology of design. Narodnoye obrazovaniye, 5, 55-61.

Koblyanskaya, E. V. (1995). Psychological aspects of social competence (Doctoral dissertation). St Petersburg.

Kunitsyna, V. N. (1995). Social competency and social intellect: Structure, functions, interrelations. In Theoretical and applied questions of psychology. St. Petersburg.

Lisitzina, T. B., Pavlova, A. V., Khanmurzina, R. R., Vlasova, V. N., Chitalin, N. A., Maksimov, I. N., \& Zakirova, V. G. (2014). Features of the Professional and Motivating Training Content Design for Students Majoring in "Tourism". Asian Social Science, 11(1), 148-154. http://dx.doi.org/10.5539/ass.v11n1p148

Lopatina, O. V., Fassakhova, G. R., Akhmetova, L. A., Gatin, R. G., Yarullina, A. S., Nikishina, S. R., \& Khairullina, E. R. (2015). The Technology of Forming the Students' Research Competence in the Process of Learning a Foreign Language. Asian Social Science, 11(3), 152-157.

Markova, A. K. (1990). Psychological analysis of a teacher's professional competency (p. 8). Soviet pedagogics.

Masalimova, A. R., Schepkina, N. K., Leifa, A. V., Shaidullina, A. R., \& Burdukovskaya, E. A. (2014). Mentoring perfection in modern enterprises conditions: practical recommendations. American Journal of Applied Sciences, 11(7), 1152-1156. http://dx.doi.org/10.3844/ajassp.2014.1152.1156

Masalimova, A. R., Zakirova, V. G., Chernova, Y. A., Drovnikov, A. S., Shaidullina, A. R., \& Sakhieva, R. G. (2014). Structure and content of mentors psychological and pedagogical training curriculum. Life Science Journal, 11(7s), 381-386.

Merzon, E. R., Fayzullina, A. R., Ibatullin, R. R., Krylov, D. A., Schepkina, N. K., Pavlushkina, T. V., \& Khairullina, E. R. (2015). Organizational and Pedagogical Conditions of Academic Mobility Development of Students at School of Higher Professional Education. Review of European Studies, 7(1), 46-51.

Mokeyeva, E. V., Zakirova, V. G., \& Masalimova, A. R. (2015). Tolerant Pedagogic Space as a Condition of Non-Violence Position Education among Elementary School Pupils. Review of European Studies, 7(4), 216-220. http://dx.doi.org/10.5539/res.v7n4p216

Romulus, O. V. (2003). Social competence as one of the basic characteristics of a personality. In Man and society: History and modern times (pp. 132-135). Voronezh.

Rubin, K. H. (2001). Interpersonal problem solution and social competency in children's behavior. St. Petersburg: Piter.

Sakhieva, R. G., Ibatullin, R. R., Biktemirova, M. K., Valeyeva, G. K., Pchelina, O. V., Valeyeva, N. Sh., Minsabirova, V. N., \& Khairullina, E. R. (2015). The Essential, Objective and Functional Characteristics of the Students' Academic Mobility in Higher Education. Review of European Studies, 7(3), 335-340. http://dx.doi.org/10.5539/res.v7n3p335

Selman, R. (1997). Stages of social intelligence development. In G. A. Tzukerman (Ed.), Psychology of development: a task for parents and their pedagogues (pp. 51-54). Moscow-Riga. 
Shaidullina, A. R., Fassakhova, G. R., Valeyeva, G. K., Khasanova, G. B., Komelina, V. A., \& Ivanova, T. L. (2015). A Comparative Research on Levels of Students' Formation Skills of Their Career Advancement Portfolio in Secondary and Higher Education Systems. Asian Social Science, 11(1), 375-379.

Sibgatova, K. I., Mirzagalyamova, Z. N., Pupysheva, E. L., Mirzanagimova, F. I., Shkinderova, I. N., Nuriyeva, E. N., Masalimova, A. R., \& Schepkina, N. K. (2015). The Educational Institution Teachers and Professional Community Representatives' Readiness Formation for the Joint Pupils' Career Guidance Implementation. Review of European Studies, 7(1), 74-79.

Thorndike, E. L. (1920). Intelligence and its use. Harper's Magazine, 140, 227-335.

Vachkov, I. V. (2005). The basis of group training technology, Psychotechnics. Moscow: Publishers "Os-89".

Valeeva, R. A., \& Karimova, L. A. (2014). Research of Future Pedagogue-Psychologists' Social Competency and Pedagogical Conditions of its Formation. Procedia-Social and Behavioral Sciences, 131, 40-44. http://dx.doi.org/10.1016/j.sbspro.2014.04.076

Valeeva, R. A., Koroleva, N. E., \& Sakhapova, F. K. (2014). Civic education of the technical university students in foreign language classes. Review of European Studies, 7(1), 176-181. http://dx.doi.org/10.5539/res.v7n1p176

Vardanyan, Y. V. (1999). The structure and development of a specialist with higher education professional competency (Doctoral dissertation). Moscow.

Verbitsky, A. A. (2004). Competence approach and the theory of contextual learning. Moscow: ICPKPS.

Vlasova V. K., Kirilova G. I., \& Masalimova, A. R. (2015). Information and Logistic Foundations of Pedagogical Education Design and Content Education. Review of European Studies, 4(7), 54-58. http://dx.doi.org/10.5539/res.v7n4p54

Vorontsov, D. B. (2006). Formation of social competence of adolescents at risk (Doctoral dissertation). Kostroma.

Zakirova, V. G., \& Koletvinova, N. D. (2014). Paradigm of future primary school teachers' vocational training. Life Science Journal, 11(4), 441-447.

Zaripova, I. M., Shaidullina, A. R., Upshinskaya, A. Y., Sayfutdinova, G. B., \& Drovnikov, A. S. (2014). Modeling of Petroleum Engineers Design-Technological Competence Forming in Physical-Mathematical Disciplines Studying Process. American Journal of Applied Sciences, 11(7), 1049-1053. http://dx.doi.org/10.3844/ajassp.2014.1049.1053

Zeer, E. F. (2003). Psychology of vocational education. Moscow: Publishing House of the Moscow psycho-social institution.

Zimnyaya, I. A. (2006). Competency based approach. What's its role in the system of modern approaches to education issues? Theoretical and methodological aspects. Higher education today: Reforms, innovations, experience, 8 .

\section{Copyrights}

Copyright for this article is retained by the author(s), with first publication rights granted to the journal. This is an open-access article distributed under the terms and conditions of the Creative Commons Attribution license (http://creativecommons.org/licenses/by/3.0/). 